\title{
Penilaian Kinerja di Perusahaan Daerah Air Minum (PDAM) Kabupaten Pasuruan dari Perspektif Finansial dan
} Non Finansial

\section{Prilia Herdiyani Manafe}

\author{
Accounting Department, Faculty of Economy \\ Maulana Malik Ibrahim, State Islamic University of Malang, \\ Indonesia
}

\begin{abstract}
This research aims to know the performance of PDAM through financial and non-financial perspective. This research employs descriptive qualitative approach. The data are collected by observation, interview, questionnaires and documentation. The data analysis is conducted by measuring each perspective, the financial and non-financial perspective, which consists of customers, internal business, learning, and growth. The result of the research shows that, overall, the performance of PDAM in Pasuruan Regency is good. It is indicated by the high value acquisition from each perspective. Based on the financial perspective to measure the profitability ratio, the ratio indicating the highest increase is ROI, compared to other ratios namely ROE, operating expenses ratio, and NPM. The customer's perspective which is measured using questionnaires shows the index value of the highest customer's satisfaction criteria. In addition, as seen from customers' acquisition and retention, the company is able to retain its customers, but there is an increase in customer complaints number. Based on the company internal business perspective, the company has given good services for the customers. The learning and growth perspective show a good performance, overall.
\end{abstract}

Keywords : Financial Perspective, Non-Financial Perspective

\section{PENDAHULUAN}

Air merupakan kebutuhan yang sangat penting bagi kelangsungan hidup manusia, tanpa air tidak akan ada kehidupan di bumi. Tubuh manusia $65 \%$-nya terdiri atas air. Bumi mengandung sejumlah besar air, lebih kurang 1,4 x $109 \mathrm{~km} 3$, yang terdiri atas samudera, laut, sungai, danau, gunung es, dan sebagainya. Namun dari sekian banyak air yang terkandung di bumi hanya $3 \%$ yang berupa air tawar yang terdapat dalam sungai, 
danau, dan air tanah (Agustina, 2007).

Kebutuhan terhadap air untuk keperluan sehari-hari di lingkungan rumah tangga, ternyata berbeda untuk tiap tempat, tiap tingkatan kehidupan atau untuk tiap bangsa dan negara. Semakin tinggi taraf kehidupan, semakin meningkat pula kebutuhan manusia terhadap air. Karena begitu pentingnya peranan air ini dalam kehidupan masyarakat, maka Pemerintah harus memberi perhatian khusus (Simanjuntak, 2012).

Diperkirakan sekitar 1 miliar orang di seluruh dunia tidak menikmati air bersih dan 1 miliar lagi harus hidup hanya dengan air yang sangat terbatas setiap harinya. Di samping itu, masih ada 1,7 miliar manusia lainnya yang hidup tanpa sanitasi. Antara tahun 1970 dan tahun 1988, jumlah rumah tangga perkotaan di negaranegara dunia ketiga yang tidak dilengkapi dengan sarana sanitasi telah melonjak sampai $247 \%$ dan keluarga yang tidak dilengkapi dengan air bersih meningkat $56 \%$ (Todaro, 2000).

Melihat pentingnya air dalam kehidupan masyarakat, pemerintah telah membuat UU dan peraturan yaitu pasal 33 pasal 33 ayat 2 UUD 1945 berbunyi " Cabang-cabang produksi yang penting bagi Negara dan menguasai hajat hidup orang banyak dikuasai oleh Negara". Ayat 3 berbunyi "Bumi, air, dan kekayaan alam yang terkandung di dalamnya dikuasai oleh negara dan digunakan sebesar-besarnya untuk kemakmuran rakyat". Aturan dan penanganan masalah air ini tidak hanya diperingkat nasional tetapi juga oleh pemerintah daerah, sesuai dengan pasal 33 ayat 2 dan 3 tersebut.

Menurut UU No 5 tahun 1962, Perusahaan Daerah Air Minum (PDAM), merupakan suatu kesatuan usaha milik pemerintah daerah yang memberikan jasa pelayanan dan menyelenggarakan kemanfaatan umum dibidang air minum (dalam Widyaningrum, 2004). PDAM atau Perusahaan Daerah Air Minum merupakan salah satu unit usaha milik daerah, yang bergerak dalam distribusi air bersih bagi masyarakat umum. PDAM terdapat di setiap provinsi, kabupaten, dan kotamadya di seluruh Indonesia. PDAM merupakan perusahaan daerah sebagai sarana penyedia air bersih yang diawasi dan dimonitor oleh aparat-aparat eksekutif maupun legislatif daerah (Wikipedia Bahasa Indonesia).

Sesuai dengan ketentuan dalam undang-undang nomor 7 tahun 2004 tentang Sumber Daya Air dan Undang-Undang No 32 Tahun 2004 tentang Pemerintah Daerah, diamanatkan bahwa 
pengembangan system penyediaan dan pelayanan air minum kepada masyarakat merupakan tanggung jawab Pemerintah Dan Pemerintah/ Kabupaten/ Kota yang diselenggarakan dalam rangka mewujudkan kesejahteraan.

Melihat pentingnya air dalam kehidupan masyarakat, pemerintah telah membuat UU dan peraturan yaitu pasal 33 pasal 33 ayat 2 UUD 1945 berbunyi " Cabang-cabang produksi yang penting bagi Negara dan menguasai hajat hidup orang banyak dikuasai oleh Negara". Ayat 3 berbunyi "Bumi, air, dan kekayaan alam yang terkandung di dalamnya dikuasai oleh negara dan digunakan sebesar-besarnya untuk kemakmuran rakyat". Aturan dan penanganan masalah air ini tidak hanya diperingkat nasional tetapi juga oleh pemerintah daerah, sesuai dengan pasal 33 ayat 2 dan 3 tersebut.

Menurut UU No 5 tahun 1962, Perusahaan Daerah Air Minum (PDAM), merupakan suatu kesatuan usaha milik pemerintah daerah yang memberikan jasa pelayanan dan menyelenggarakan kemanfaatan umum dibidang air minum (dalam Widyaningrum, 2004). PDAM atau Perusahaan Daerah Air Minum merupakan salah satu unit usaha milik daerah, yang bergerak dalam distribusi air bersih bagi masyarakat umum. PDAM terdapat di setiap provinsi, kabupaten, dan kotamadya di seluruh Indonesia. PDAM merupakan perusahaan daerah sebagai sarana penyedia air bersih yang diawasi dan dimonitor oleh aparat-aparat eksekutif maupun legislatif daerah (Wikipedia Bahasa Indonesia).

Sesuai dengan ketentuan dalam undang-undang nomor 7 tahun 2004 tentang Sumber Daya Air dan Undang-Undang No 32 Tahun 2004 tentang Pemerintah Daerah, diamanatkan bahwa pengembangan system penyediaan dan pelayanan air minum kepada masyarakat merupakan tanggung jawab Pemerintah Dan Pemerintah/ Kabupaten/ Kota yang diselenggarakan dalam rangka mewujudkan kesejahteraan masyarakat dengan menjamin standar kebutuhan pokok air minum bagi masyarakat yang memenuhi syarat kualitas, kuantitas dan kontinuitas yang kebijakan pelaksanaannya dilaksanakan oleh Perusahaan Daerah Air Minum (PDAM).

PDAM Kabupaten Pasuruan merupakan BUMD yang memiliki tujuan jangka pendek untuk meningkatkan pendapatan asli daerah dan bergerak dibidang jasa dalam penyediaan air bersih. Sedangkan tujuan jangka panjangnya adalah 


\section{Penilaian Kinerja di Perusahaan Daerah Air Minum}

mengusahakan dan menyelenggarakan pengelolaan air bersih guna meningkatkan kesejahteraan masyarakat yang mencakup aspek sosial, kesejahteraan dan pelayanan umum yang dikelola secara profesional dengan prinsip ekonomi perusahaan. Oleh karena itu, dibentuklah badan pengawas yang bertugas menilai keberhasilan direksi dalam mengelola PDAM bersangkutan setiap tahun. Salah satu cara untuk mengetahui pencapaian tujuan perusahaan adalah dengan mengukur kinerja perusahaan. PDAM kabupaten pasuruan melakukan penilaian kinerjanya dengan berpedoman pada Keputusan Menteri Dalam Negeri No 47 Tahun 1999 Tanggal 31 Mei 1999 yang berisikan tentang pedoman pengukuran kinerja yang dilihat dari dua aspek yaitu finansial dan non finansial.

Menurut (Yuwono, 2003:23) penilaian kinerja merupakan tindakan penilaian yang dilakukan terhadap berbagai aktivitas dalam rantai nilai yang ada pada perusahaan. Kebanyakan penilaian kinerja perusahaan menggunakan informasi keuangan sebagai single indicator dalam alat ukur kinerja perusahaan dan telah digunakan secara luas. Tetapi menurut (Kaplan dan Norton, 2007:7) ukuran finansial sebagai single indicator mempunyai banyak keterbatasan, salah satunya adalah ukuran finansial yang hanya menjelaskan berbagai peristiwa masa lalu yang cocok untuk perusahaan abad industry dimana investasi dalam kapabilitas jangka panjang dan hubungan dengan pelanggan bukanlah factor penting dalam mencapai keberhasilan.

Penilaian atau pengukuran kinerja merupakan salah satu factor yang penting dalam perusahaan. Selain digunakan untuk menilai keberhasilan perusahaan, penilaian kinerja juga dapat digunakan sebagai dasar untuk mengevaluasi hasil kerja dari periode yang lalu. Sehubungan dengan hal itu, penilaian kinerja sebaiknya dilakukan secara komprehensif, sehingga pengambilan keputusan berkaitan dengan strategi dapat dilakukan secara menyeluruh. Dengan demikian strategi tersebut akan dapat mengakomodasi setiap perspektif yang terlibat dalam menentukan keberhasilan perusahaan. Oleh karena itu, berkembanglah sistem penilaian kinerja dengan basis yang lebih komprehensif yaitu tidak hanya menggunakan financial perspective untuk mengukur kinerja perusahaan tetapi juga menggunakan non financial perspective.

Sehubungan dengan hal tersebut, Robert S Kaplan dan David P Norton tahun 1992 memperkenalkan suatu alat untuk pengukuran kinerja perusahaan yaitu, Balanced Scorecard. Balanced 
Scorecard meliputi tolak ukur keuangan yang menerangkan akibat dari aktivitas-aktivitas yang telah dilakukan suatu organisasi dan dilengkapi dengan tolak ukur operasional terhadap kepuasan pelanggan, proses internal serta aktivitas inovasi dan perbaikan organisasi. Jadi Balanced Scorecard merupakan suatu framework untuk mengkomunikasikan misi dan strategi kemudian menginformasikan kepada seluruh anggota organisasi tentang factor-faktor yang menjadi penentu sukses organisasi saat ini dan di masa mendatang.

Balanced Scorecard merupakan suatu sistem yang memungkinkan perusahaan untuk meningkatkan profitabilitas dan keunggulan kompetitif dalam jangka panjang melalui pengukuran kinerja dari berbagai aspek. Balanced Scorecard menggabungkan pengukuran kinerja dari sisi finansial dengan operasi dan pelanggan. Menurut Kaplan dan Norton, Balanced Scorecard bertujuan mengukur kinerja perusahaan dari empat aspek yaitu: customer (pelanggan), proses intern perusahaan, inovasi dan pembelajaran, serta finansial. Oleh karena itu pelanggan, proses intern perusahaan, inovasi dan pembelajaran, dan finansial harus dipertimbangkan dalam menyusun visi dan strategi (Wardhani, 1999: 43-50).

Menurut (Jeno, 1997:65-69) ada tiga alasan mengapa perusahaan memerlukan Balanced Scorecard yaitu:

a. Balanced Scorecard tidak hanya memfokuskan pada ukuran keuangan semata, tapi juga memperhatikan sejumlah ukuran yang terintegrasi sehingga dapat mengaitkan pelanggan saat ini, proses bisnis internal, dan karyawan untuk pencapaian profit dalam jangka panjang.

b. Balanced Scorecard menyatukan berbagai elemen persaingan bisnis yang harus diperhatikan perusahaan ke dalam satu laporan manajemen yang lengkap.

c. Balanced Scorecard memberi gambaran operasi perusahaan secara menyeluruh, sehingga perbaikan di satu aspek tidak merugikan aspek lainnya. Artinya optimasi perusahaan dilakukan secara maksimal.

Adapun alasan penulis memilih PDAM sebagai objek penelitian adalah berdasarkan penjajagan awal bahwa penilaian kinerja yang selama ini dilakukan di PDAM Kabupaten Pasuruan masih menggunakan pendekatan tradisional yaitu penilaian kinerja yang bersumber dari informasi keuangan perusahaan saja. Oleh karena itu, penulis mencoba untuk mengaplikasikan penilaian dengan menggunakan metode Balanced Scorecard agar di 


\section{Penilaian Kinerja di Perusahaan Daerah Air Minum}

dalam penilaian kinerja tersebut dapat berimbang antara keuangan dan non keuangan. Berdasarkan uraian di atas penulis menelitu Penilaian Kinerja Di Perusahaan Daerah Air Minum (PDAM) Kabupaten Pasuruan Dengan Menggunakan Perspektif Finansial Dan Non Finansial.

\section{TINJAUAN PUSTAKA}

\section{Penilaian Kinerja Perusahaan Daerah Air Minum Di Indonesia}

PDAM sebagai organisasi pelayanan publik, menyadang misi untuk memberikan pelayanan yang baik bagi kebutuhan masyarakat. Sedangkan, sebagai suatu badan usaha tentunya dituntut untuk dapat dikelola berdasarkan asas ekonomi perusahaan yang sehat agar paling tidak mampu membiayai dirinya sendiri, dan bahkan dapat memberikan sumber penerimaan bagi pemerintah daerah setempat (Mukhlis.1997:18). Harundono (1995) berpendapat bahwa PDAM sebagai pengelola pelayanan air minum di daerah adalah perusahaan daerah yang menangani kepentingan umum baik melayani semua kalangan masyarakat. Dan sebagai perusahaan daerah bukan semata-mata mencari keuntungan akan tetapi disisi lain harus dikelola secara sehat sesuai prinsip-prinsip ekonomi perusahaan. Keuntungan juga merupakan hal yang penting karena diperlukan untuk mempertahankan kontinuitas pelayanan dan pengembangan usaha.

Penelitian terdahulu terhadap kinerja PDAM di berbagai daerah di Indonesia dilakukan oleh Farohma, (2001) dan Suwartono, (2002). Farohma (2001) meneliti tentang kinerja aspek keuangan dan aspek opersional PDAM Tirta Musi Palembang dengan membandingkan dua PDAM Surabaya dan PDAM Kota Bogor dengan mengunakan data tahun 1998. Penelitian ini dapat menggambarkan perbandingan kinerja satu PDAM dengan dua PDAM lainnya pada tahụ yang sama. Metode yang digunakan dalam penilaian kinerja pada aspek keuangan menggunakan Kepmendagri No.690.900.327 Tahun 1994 tentang Pedoman Penilaian Dan Pemantauan Kinerja Keuangan PDAM, sedangkan penilaian kinerja aspek pelayanan dilakukan berdasarkan dengan Kepmendagri No.47 Tahun 1999 tentang Penilaian. Hasil penelitian ini menunjukkan bahwa kinerja keuangan PDAM Tirta Musi Palembang, PDAM Surabaya dan PDAM Kota Bogor pada kondisi yang kurang sehat dan pada aspek pelayanan menunjukakan kinerja belum memuaskan. Kelemahan dari penelitian ini bahwa penilaian 
kinerja pada aspek keuangan menggunakan Kepmendagri No.690.900.327 Tahun 1994 terdiri dari tiga indikator yaitu struktur hutang, tingkat eqiutas dan tingkat keuntungan, bahwa Kepmendagri No.690.900.327 Tahun 1994 kemudian diganti dengan Kepmendagri No.47 Tahun 1999 Tentang Pedoman Penilaian Kinerja PDAM yang lebih luas cakupan penilaian kinerjanya yaitu meliputi aspek keuangan, aspek operasional, dan aspek administrasi.

Suwartono (2002) meneliti tentang kinerja PDAM Kabupaten Sleman berdasarkan Kepmendagri No.47 Tahun 1999 Tentang Pedoman Penilaian Kinerja PDAM pada aspek keuangan dan aspek operasional dan membandingkan dengan kinerja dari tiga kabupaten lain dalam Propinsi DIY, berdasarkan data dari tahun 1997-2000. Berdasarkan penilaian kinerja yang telah dilakukan kemudian dianalisis permasalah-permasalahan yang muncul dari aspek keuangan dan atau aspek operasional yang menjadi hambatan pencapaian keberhasilan yang lebih tinggi. Dengan menggunakan metode analisis Strength, Weakness, Opportunity dan Threat (SWOT) aspek keuangan, aspek operasional serta permasalah yang dapat diidentifikasi kemudian dirumuskan dalam strategi pemberdayaan kinerja PDAM lebih lanjut.

\section{Balanced Scorecard}

Menurut Kaplan dan Norton (1996), Balanced Scorecard terdiri dari dua kata yaitu Scorecard Berarti kartu yang digunakan untuk mencatat skor/nilai hasil kinerja seseorang yang nantinya akan digunakan untuk membandingkan antara dengan hasil kinerja yang sesungguhnya dengan apa yang diharapkan atau ditetapkan sebelumnya.

Balanced Dimaksudkan untuk menunjukkan bahwa kinerja personel atau karyawan diukur secara seimbang, yang harus dilihat dari dua aspek yaitu: keuangan dan non keuangan, jangka pendek dan jangka panjang, serta intern maupun ekstern.

Menurut Kaplan dan Norton (1996) langkah-langkah Balanced Scorecard meliputi 4 (empat) proses manajemen, yaitu :
a. Menerjemahkan visi, misi dan strategi perusahaan.
b. Mengkomunikasikan dan mengaitkan berbagai tujuan dan ukuran strategis.
c. Merencanakan, menetapkan sasaran, menyelaraskan berbagai inisiatif strategis.
d. Memberikan umpan balik dan pembelajaran strategis. 


\section{METODOLOGI PENELITIAN}

Desain penelitian yang akan digunakan adalah deskriptif, yaitu penelitian yang dilakukan untuk memperoleh gambaran yang sebenarnya tentang penilaian kinerja di pdam dengan menggunakan perspektif finansial dan non finansial. Selain itu, jenis data yang dikumpulkan adalah data kualitatif. Menurut Sugiyono (2012) metode kualitatif digunakan untuk meneliti pada kondisi objek alamiah. Perhitungan kuesioner yang terkait dengan komponen penilaian kinerja dalam perspektif pelanggan dan pembelajaran dan pertumbuhan, diolah menggunakan perhitungan yang dikuantitatifkan dengan melalui uji reliable, uji validitas dan skala likert.

Penelitian ini dilakukan di PDAM Tirta Dharma Kabupaten Pasuruan, dengan pertimbangan bahwa PDAM Kabupaten Pasuruan merupakan unsur pelaksana pemerintah daerah yang mempunyai kedudukan, fungsi, dan tugas yang cukup penting dalam kegiatan penyediaan air bersih bagi masyarakat Pasuruan dan sekitarnya.

\section{HASIL PENELITIAN}

\section{Penilaian Kinerja Perspektif Finansial}

Sasaran dari perpektif keuangan ini adalah untuk memenuhi harapan dari shareholder. Salah satunya adalah dengan cara memperbaiki kinerja operasi perusahaan tersebut. Sehingga profit yang dihasilkan dapat meningkat.

\section{Return on Equity}

Net rate of ROE menunjukkan besarnya ekuitas yang digunakan untuk menghasilkan laba bersih. Untuk tahun 2011 diperoleh rasio sebesar $60,50 \%$, ini berarti setiap Rp 1,00 dari ekuitas dapat menghasilkan laba bersih (setelah pajak) $\mathrm{Rp} 0,60$. Untuk tahun 2012 Return On Equity memperlihatkan angka 46,43\%, ini berarti setiap $\mathrm{Rp}$ 1,00 dari ekuitas dapat menghasilkan laba bersih (setelah pajak) Rp 0,46. Rasio tahun ini mengalami penurunan sebesar $14,07 \%$, hal ini disebabkan karena peningkatan laba yang terjadi pada tahun tersebut. Tahun 2013 diperoleh rasio sebesar 33,70\%, berarti bahwa setiap Rp 1,00 dari ekuitas dapat menghasilkan laba bersih (setelah pajak) Rp 0,33. Rasio ini mengalami penurunan dari tahun sebelumnya, hal ini disebabkan karena laba yang diperoleh tahun ini lebih kecil dari pada laba 
yang diperoleh tahun sebelumnya.

\section{Return on Invesment}

Net rate of ROI menunjukkan besarnya total aktiva yang digunakan untuk menghasilkan laba bersih (setelah pajak). Net rate of ROI selama tiga tahun terakhir menunjukkan angka positif, masing-masing sebesar: 5,87\%; 9,59\% dan 5,20\%. Tahun 2011 diperoleh net rate of ROI sebesar 5,87\%, berarti setiap Rp 1,00 dari total aktiva dapat digunakan untuk menghasilkan laba bersih (sesudah pajak) Rp 0,05. Pada tahun 2012 rasio sebesar 9,59\%, ini berarti setiap $\mathrm{Rp} 1,00$ keseluruhan aktiva perusahaan dapat digunakan untuk menghasilkan laba bersih (setelah pajak) Rp 0,09. Net rate of ROI tahun 2012 ini meningkat jika dibandingkan dengan tahun 2011, yaitu sebesar 3,72\%. Peningkatan ini disebabkan oleh kenaikan laba yang diperoleh perusahaan diimbangi dengan kenaikan jumlah aktiva. Kenaikan laba tahun 2012 diakibatkan karena jumlah pelanggan yang bertambah besar sehingga meningkatkan volume penjualan air yang pada akhirnya berpengaruh terhadap.

peningkatan pendapatan usaha serta efisiensi biaya usaha. Pada tahun 2013 diperoleh rasio sebesar 5,20\%, berarti setiap Rp 1,00 keseluruhan aktiva perusahaan dapat digunakan untuk menghasilkan laba bersih (setelah pajak) $\mathrm{Rp} 0,05$. Rasio tahun ini mengalami penurunan sebesar $4,39 \%$ dari tahun sebelumnya, hal ini disebabkan oleh penurunan laba yang diperoleh perusahaan tahun 2013.

\section{Rasio Beban Operasional}

Hasil perhitungan operating ratio untuk tahun 2011, 2012 dan 2013 masing-masing menunjukkan angka sebesar 38,67\%; $37,92 \%$ dan $37,74 \%$. Operating ratio tahun 2011 sebesar 38,67\%, berarti setiap Rp 1,00 dari penjualan/ pendapatan usaha, sebesar Rp 0,38 terserap untuk menutup beban usaha perusahaan. Tahun 2012 diperoleh rasio sebesar 37,92\%, hal ini berarti setiap $\mathrm{Rp} 1,00$ pendapatan usaha perusahaan, sebesar $\mathrm{Rp} 0,37$ terserap untuk menutup beban usaha perusahaan. Pada tahun ini rasio mengalami penurunan sebesar $0,75 \%$ dari tahun sebelumnya. Penurunan rasio ini disebabkan oleh persentase kenaikan pendapatan usaha lebih besar dari pada persentase kenaikan beban usaha. Untuk tahun 2013, operating ratio sebesar $37,74 \%$, ini berarti setiap $R p 1,00$ pendapatan usaha perusahaan, sebesar $\mathrm{Rp} 0,37$ akan terserap untuk menutup beban usaha. Operating ratio tahun ini mengalami penurunan sebesar 0,18\% dari tahun 2012. 


\section{Net Profit Margin}

Net profit margin tahun 2011, 2012 dan 2013 masing-masing menunjukkan angka: $10,63 \% ; 13,90 \%$ dan $6,90 \%$. Untuk tahun 2011 , total net profit margin $10,63 \%$ berarti setiap $\mathrm{Rp} 1,00$ dari pendapatan usaha sebesar Rp. 0,10 terserap untuk menutup laba bersih perusahaan. Untuk tahun 2012 rasio sebesar 13,90\%, ini berarti setiap Rp 1,00 dari pendapatan usaha sebesar Rp 0,13 terserap untuk menutup laba bersih perusahaan. Rasio tahun ini mengalami peningkatan sebesar 3,27\% dari tahun sebelumnya. Tahun 2013 rasio sebesar $6,90 \%$ berarti setiap $R p 1,00$ dari pendapatan usaha sebesar Rp. 0,06 terserap untuk menutup laba bersih perusahaan. Net profit margin tahun ini mengalami penurunan sebesar 7\% dari tahun 2012.

Berdasarkan hasil analisis rasio rentabilitas, manajemen perusahaan dapat mengetahui seberapa besar kemampuan perusahaan dalam menghasilkan laba dan kemajuan kinerja perusahaan selama tiga tahun terakhir, sehingga perusahaan dapat mengambil keputusan-keputusan yang bertujuan untuk lebih meningkatkan kinerja perusahaan serta efisiensi dan efektivitas perusahaan dalam menjalankan kegiatan operasinya. Dalam 3 (tiga) tahun terakhir PDAM Kabupaten Pasuruan masih memperoleh laba walaupun laba tersebut tidak sebagaimana yang diharapkan, hal ini masih terlihat dari kemampuan perusahaan dalam menghasilkan rentabilitas yang ditunjukkan oleh net rate of ROE dan net rate of ROI. Indikator tersebut setiap tahun mengalami perubahan sejalan dengan peningkatan maupun penurunan laba yang terjadi.

\section{Perspektif Keuangan (Bobot $30 \%$ )}

Sasaran Ukuran Hasil Bobot Target Realisasi Skor

Strategi

-Rasio

- Rasio

Rentabilitas

Rentabilitas

$3 \%$

$90 \%$

$80 \%$

- Rasio -ROE

Likuiditas -Rasio

- Rasio beban

Solvabilitas operasional

-ROI

-NPM

- Rasio

Likuiditas

-cash ratio

\section{$2 \%$}

$4 \%$

$90 \%$

$95 \%$

$80 \%$

1,8

$3 \%$

$90 \%$

$90 \%$

3,7

2,6

$\begin{array}{llll}3 \% & 90 \% & 85 \% & 2,8\end{array}$

$3 \% \quad 90 \%$

$80 \%$

2,7

$4 \%$

$90 \%$

$85 \%$

3,7

$\begin{array}{llll}4 \% & 95 \% & 90 \% & 3,7\end{array}$


Prilia Herdiyani Manate

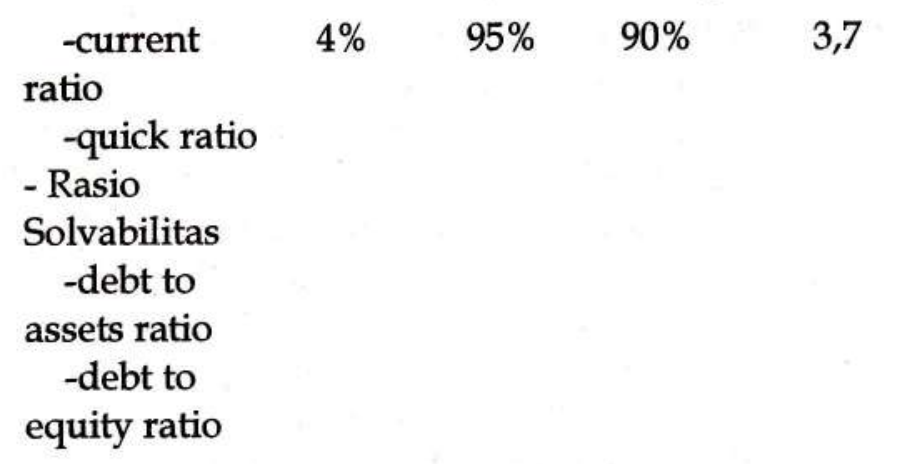

Sumber: data diolah

\section{Penilaian Kinerja Perspektif Non Finansial}

Sasaran dari perspektif pelanggan dimaksudkan untuk meningkatkan kepuasan, retensi, akuisisi, dan loyalitas pelanggan. Sasaran dari pada strategi customer perspektif pada PDAM adalah untuk meningkatkan kepuasan pelanggan dan peningkatan jumlah pelanggan. Adapun pengukuran kinerja yang digunakan adalah tingkat pemerolehan pelanggan atau akuisisi pelanggan, retensi pelanggan, dan klaim pelanggan.

Berdasarkan data pelanggan selama 3 tahun (tahun 2011-2013) yang menunjukan bahwa rata-rata pelanggan lama pertahun dari PDAM Kab. Pasuruan sebesar 20.441 orang, sedangkan pelanggan baru sebesar 654 orang dan jumlah pelanggan yang complain sebesar 2.026 .

\section{Akuisisi pelanggan}

Tingkat akuisisi perlu diperhitungkan guna untuk mengetahui jumlah pelanggan baru yang berhasil ditarik oleh perusahaan dalam suatu periode tertentu. Dari 3 tahun terakhir perusahaan telah menunjukkan adanya peningkatan jumlah pelanggan dan akuisisi, pelanggan pada tahun tersebut. Total akuisisi tahun 2012 dan 2013 mengalami peningkatan sebesar $3,10 \%$ dan $4,12 \%$.

Hal ini membantu perusahaan dalam menjalankan kegiatan usahanya terbukti dari strategi-strategi yang dilakukan dalam menarik pelanggan baru adalah dengan diadakannya gebyar pasang baru dengan diskon untuk menciptakan minat masyarakat menjadi pelanggan PDAM selain itu apabila terjadi kerusakan pada meter air pelanggan maka perusahaan akan melakukan penggantian secara gratis. 


\section{Penilaian Kinerja di Perusahaan Daerah Air Minum}

\section{Retensi Pelanggan}

Retensi pelanggan adalah suatu tingkat yang menunjukkan kemampuan perusahaan dalam mempertahankan hubungan dengan pelanggan.

Data dari tabel di atas menunjukkan bahwa kinerja pada perusahaan daerah air minum tahun 2012 mengalami penurunan sebesar $96,89 \%$ dan pada tahun 2013 menurun sebesar $95,87 \%$. Hal ini dikarenakan komplain pelanggan yang tidak segera terselesaikan, terjadinya pengeroposan pipa, dan kebocoran pipa yang tidak segera di atasi. Berkaitan dengan hal tersebut tentu saja ada upaya-upaya yang dilakukan oleh PDAM dalam meningkatkan kinerjanya yaitu dengan meningkatkan cakupan pelayanan, mengupayakan komplain pelanggan dan pengendalian tingkat kebocoran air.

Komplain Pelanggan

Dari komplain yang diterima perusahaan tahun 2012 mengalami peningkatan sebesar 0,71\% dan tahun 2013 meningkat sebesar $3,67 \%$. Ini menunjukkan komplain yang diterima perusahaan setiap tahunnya meningkat lebih tinggi dari tahuntahun sebelumnya. Hal ini menunjukkan bahwa perusahaan belum dapat mengendalikan kendala-kendala yang datang dari pelanggan. Perusahaan harus lebih memperbaiki kinerjanya dan harus mampu mengatasi klaim-klaim dari para pelanggannya.

Dari balanced scorecard yang dilihat dari masing-masing perspektif, memperoleh skor keseluruhan yaitu sebesar 94,2 dan dikategorikan sangat baik. Dari matriks balanced scorecard tersebut dapat dilihat sasaran strategik mana yang belum mencapai target yang telah ditetapkan untuk dilakukan sebuah evaluasi kinerja dengan tujuan dapat memenuhi target yang ditentukan, seperti pada persepektif pelanggan dan perspektif pembelajaran dan pertumbuhan, jumlah komplain pelanggan yang diterima perusahaan semakin meningkat lebih tinggi dari tahun-tahun sebelumnya, ini berarti bahwa perusahaan belum dapat mengendalikan klaim-klaim yang datang dari para pelanggannya sedangkan pada perspektif pembelajaran dan pertumbuhan, jumlah retensi karyawan meningkat pada tahun-tahun berikutnya.

\section{KESIMPULAN}

Berdasarkan hasil penilaian kinerja perusahaan dengan menggunakan perspektif finansial dan non finansial yang telah dilakukan, maka ditarik kesimpulan diantaranya Penilaian kinerja 
dengan menggunakan perspektif financial. Rasio Rentabilitas, yang terdiri dari ROE, Rasio Beban Operasional, ROI dan NPM. Return On Equity (ROE) dan rasio beban operasional mengalami penurunan diakibatkan oleh kenaikan pendapatan non air yang terdiri dari jasa pemasangan instalasi, jasa pemasangan persil, pergantian meter air pelanggan serta biaya sumber air yang terdiri dari beban operasi, beban pemeliharaan, beban air baku dan beban penyusutan. Sedangkan untuk ROI terjadi kenaikan tahun 2012 diakibatkan oleh jumlah pelanggan yang bertambah banyak sehingga meningkatkan volume penjualan air yang pada akhirnya berpengaruh terhadap peningkatan pendapatan usaha serta efisiensi biaya usaha.

Rasio likuiditas yang terdiri dari cash rasio, current rasio dan quick rasio. Pada perhitungan cash rasio dan current rasio menunjukkan peningkatan tahun 2012, yang disebabkan oleh kenaikan aktiva lancar dan penurunan jumlah hutang jangka pendek perusahaan. Quick ratio tahun 2013 mengalami penurunan sebesar 4,31\% dari tahun 2012, karena persediaan yang dikeluarkan untuk mengatasi kebocoran pipa bertambah dari tahun sebelumnya yang berpengaruh terhadap aktiva lancar.

Rasio Solvabilitas yang terdiri dari Debt to assets ratio dan Debt to equity ratio. Pada tahun 2012 mengalami penurunan dibandingkan tahun 2011 terutama karena persentase kenaikan hutang lancar yang lebih besar yang terdiri dari utang usaha, utang lainnya, serta biaya yang masih harus dibayar seperti retribusi air bawah tanah daripada persentase kenaikan ekuitas.

Penilaian kinerja dengan menggunakan perspektif non finansial Perspektif pelanggan yang terdiri dari akuisisi pelanggan, retensi pelanggan, komplain pelanggan dan kepuasan pelanggan. Akuisisi pelanggan menunjukkan adanya peningkatan jumlah pelanggan baru pada tahun 2012 dan 2013 sebesar 3,10\% dan 4,12\% karena diadakannya gebyar pasang baru dan diskon. Pelanggan lama mengalami penurunan pada tahun 2012 dan 2013 sebesar $96,89 \%$ dan $95,87 \%$ disebabkan oleh kompain pelanggan yang tidak segera diselesaikan.

Komplain pelanggan menunjukkan bahwa perusahaan belum dapat mengendalikan kendala-kendala yang terjadi pada pelanggan. Kepuasan pelanggan menggunakan kuesioner yang disebarkan pada masing-masing pelanggan. Dari hasil kuesioner tersebut menunjukkan bahwa sebagian besar pelanggan merasa puas atas kinerja perusahaan. 
Pada perspektif finansial untuk ROE dan Rasio beban operasional perlu meningkatkan laba perusahaannya. Rasio ini mengalami penurunan dari tahun sebelumnya, hal ini disebabkan karena laba yang diperoleh tahun 2013 lebih kecil dari pada laba yang diperoleh tahun sebelumnya.

Pada perspektif pelanggan dalam hal akuisisi dan retensi pelanggan perusahaan sudah menanganinya dengan baik, hanya saja pada komplain pelanggan menunjukkan komplain yang diterima perusahaan setiap tahunnya meningkat lebih tinggi dari tahun-tahun sebelumnya. Hal ini menunjukkan bahwa perusahaan belum dapat mengendalikan kendala-kendala yang datang dari pelanggan. Perusahaan harus lebih memperbaiki kinerjanya dan harus mampu mengatasi klaim-klaim dari para pelanggannya.

Pentingnya memperbaiki kualitas air yang dialirkan ke pelanggan harus memenuhi standar kesehatan sehingga air yang diterima pelanggan layak untuk dikonsumsi. Jika tariff dasar air dinaikkan harus diimbangi dengan kualitas produk dan pelayanan PDAM, sehingga besarnya biaya yang dikeluarkan pelanggan sesuai dengan hasil yang diterima.

\section{DAFTAR PUSTAKA}

Agustina, 2007. Analisa Kinerja System Distribusi Air Bersih Pdam Kecamatan Banyumanik Di Perumnas Banyumanik (Studi Kasus Perumnas Banyumanik Kel. Srondol Wetan. Thesis Manajemen Dan Rekayasa Infrastruktur Universitas Diponegoro

Al-Qur'an al-karim dan terjemahan

Arimbawa dan Putri, 2014. Analisis Penilaian Kinerja Keuangan Dan Non Keuangan PT. BPR Dharmawarga Utama. Jurnal Akuntansi

Universitas Udayana

Devas, Nick., et.al, 1989, Keuangan Pemerintah Daerah di Indonesia, Penerbit UI Press, Jakarta.

Fandy Tjiptono dan Gregorius Chandra, 2005, Service, Quality $\mathcal{E}$ Satisfaction, Yogyakarta : ANDI

Jeno, Michael. 1997. Balanced Scorecard: Pengukuran Kinerja Yang Terkait dengan strategi. Manajemen. September-Oktober.

Jumingan. 2006. Analisis Laporan Keuangan. PT Bumi Aksara. Jakarta

Junaedi, 2002. Balanced Scorecard: Pengukuran Kinerja Pada Pemerintah Daerah. KOMPAK, No. 6, September 
Prilia Herdiyani Manate

Kaplan, Robert S, Norton, David P, The Balanced Scorecard Measures that Drive Performance, Harvard Bussiness Review, January-February 1992.

Kaplan. Robert S dan David Norton. 2000, Balanced Scorecard: Menerapkan Strategi Menjadi Aksi, Terjemahan oleh Peter R. Yosi Pasla dari Balanced Scorecard: Transalting Strategi Into Action (1996), Erlangga, Jakarta.

Kasmir. 2010. Analisis Laporan Keuangan. PT Raja Grafindo Persada. Jakarta

Keputusan Menteri Dalam Negeri No 690-069 Tahun 1992 Tentang Pola Petunjuk Teknis Pengelolaan PDAM

Kodrat Sukardi, David. 2009: Manajemen Strategi. Yogyakarta: Graha Ilmu

M. Hanafi dan Abdul Halim. 2005. Analisis Laporan Keuangan.UPP.AMP.YKPN

Mahsun, Mohamad. (2009). Pengukuran Kinerja Sektor Publik (3th ed). Yogyakarta: BPFE.

Mahsun. M. 2006. Pengukuran Kinerja Sector Public. BPFE: Yogyakarta

Michael P Todaro. 2000. Pembangunan Ekonomi Di Dunia Ketiga. Penerbit: Jakarta: Erlangga.

Mulyadi, 2001, Balanced Scorecard : Alat Manajemen Kontemporer Untuk Pelipatgandaan Kinerja Keuangan Perusahaan, Edisi Pertama, Salemba Empat, Jakarta.

Nazir. 2005. Metode penelitian, cetakan kelima. Jakarta: ghalia Indonesia.

Pabundu, Moh. 2006. Metode Riset Bisnis. Cetakan pertama. Jakarta: bumu aksara

Pande dan Putra. 2013. Penilaian Kinerja PDAM Kota Denpasar Ditinjau Dari Aspek Finansial Dan Non Finansial. Jurnal Akuntansi Universitas Udayana

Robert, S Kaplan \& David, P Norton. 1996. Balance Scorecard : Menetapkan Strategi Menjadi Aksi. Erlangga. Jakarta

Robertson, 2002, Perwujudan Akuntabilitas Instansi Pemerintah, Edisi Pertama,

Rudianto. 2013. Akuntansi Manajemen Informasi untuk Pengambilan Keputusan Strategis. Jakarta: Erlangga

Rudianto.2006. Akuntansi Manajemen, Jakarta: PT Grasindo

Selado, 2014. Analisis Kinerja Menggunakan Balanced Scorecard 
Penilaian Kinerja di Perusahaan Daerah Air Minum

Pada Perusahaan Daerah Air Minum (Studi Kasus Pada PDAM Kabupaten Batang). Skripsi Fakultas Ekonomika Dan Bisnis Universitas Diponegoro Semarang

Simamora, Bilson. 2004. Riset Pemasaran, Cetakan Pertama. Jakarta: Gramedia Pustaka Utama

Srimindarti, Ceacilia. 2004. Balanced Scorecard Sebagai Alternatif Untuk Mengukur Kinerja.

Sugiyono. 2012. Metode Penelitian Bisnis. Cetakan Kedelapan. CV Alfabeta. Bandung.

Sunyoto, Danang. 2013. Metode Penelitian Akuntansi. Cetakan Kesatu. PT Refika Aditama. Bandung

Undang-Undang No 7 Tahun 2004 Tentang Sumber Daya Air 